\title{
Functions of style in St. Augustine's Christian rhetoric
}

\author{
Ioan Milică ${ }^{\oplus}$ \\ Faculty of Letters, "Alexandru Ioan Cuza" University, Bd. Carol I 11, 700506 Iași, Romania
}

\section{Article info}

History:

Received December 16, 2014

Accepted January 4, 2015

Published January 13, 2015

Key words:

eloquence

sermon

Christian rhetoric

\begin{abstract}
The spread of Christianity determined major cultural changes all over Europe as well as in the entire world. Without further dwelling on the relationships between the new religion and the classical culture, we will show that, in the art of eloquence, the perspective of the fathers of the Christian Church favoured, on the one hand, the survival of some of the Ancient rhetorical works and led to the introduction of a religious rhetoric that gradually departed from the influence of the old models, on the other. This paper aims at synthetically and systematically describing St. Augustine's view on the importance and functions of elocution, in order to reveal the innovations brought by this scholar to the classical rhetorical canon.
\end{abstract}

\section{Introduction}

The Christian spirituality imposes a new rhetorical genre ${ }^{1}$, ars predicandi (Copeland \& Ziolkowski, 2006, p. 494), and, against the background of the participatory rhetorical tradition that it inherited and preserved, it establishes the distinction between rhetorica humana and rhetorica divina (Knape, 2008, p. 62). Moreover, the two discursive practices, the lay and the sacred, are, according to St. Ambrose (Murphy, 2001, p. 52), instantiations of distinct categories of wisdom, the human (sapientia saculi) and the divine (sapientia spiritualis). The tension between the two cultural paradigms, the pre-Christian and the Christian, engages all the great Christian scholars and believers during the first centuries of the 1st millennium and expands beyond the scope of the rhetorical art. In a letter to St. Eustochium Julia ${ }^{2}$, St. Jerome, one of the four fathers of the Western Church and a great translator of the Bible, artfully highlights the growing gap between the Ancient cultural values and the Christian spiritual universe: "What communion hath light with darkness? What concord hath Christ with Belial? What has Horace to do with Psalter, Vergil with the Gospels and Cicero with the Apostle [Paul]? ... we ought not to drink the cup of Christ and the cup of devils at the same time." (Murphy, 2001, p. 53).

In spite of the departure from the ancient models, it is not without relevance to state that the Jewish and the Greek-Latin traditions contributed differently yet consistently to the consolidation, development and refinement of discursive patterns founded on prayer and on Bible reading and exegesis. The act of oral transmission of the sacred teachings through apostolate is, in relation to the Greek-Latin rhetorical tradition, an innovation: according to James Murphy (2001, p. 273), Christ "introduced a rhetorical element which had never before operated in human history-a direct command to his followers to spread his ideas through speech." In the light of the distinction between 'to preach' and 'to teach', respected and practiced in Jesus' times, the Christian rhetorical models (the catechetical and the homiletical in particular), founded on the authority of the Bible and reinforced by the authority of the word of Christ, presumed, from the very beginning, a blend between hermeneutics and exhortation, which is well-proven

\footnotetext{
${ }^{\star}$ Email address: ioanister@gmail.com.

${ }^{1}$ A new rhetorical canon with three genres takes shape during the Middle Ages (Murphy, 2001): the art of preaching (ars predicandi), the rhetoric of poetry (ars poetrie) and the art of letter-writing (ars dictaminis).

${ }^{2}$ Born in a Christian family of Roman nobility, St. Eustochium Julia (368-419 AD) lived an ascetic life and helped St. Jerome in his missionary and scholarly activity. The Catholic Church celebrates her feast on September 28.
} 
by the sermons of Christ (Murphy, 2001, p. 278). Such a link between what appeals to the mind and what appeals to the heart led to the creation, observation and conservation of powerful discursive frames.

For the preacher, the Scripture, seen as a revealed text, becomes a unique landmark of truth, authority and ideal of eloquence. Leaning on the letter and the spirit of the sacred text and nourished on the teachings of the founders of the Church, the Christian orator is interested in voicing only the truth of faith, so, the persuasive function of his speech is doubled by a performative function. The word is embodied in and through action, just as the action must be an embodiment of the word, and so, we may say that the Christian religious rhetoric is founded on the alliance between what is said (Gr. legomena) and what is done (Gr. drōmena) (Dowden, 2007, p. 320-333).

The communicative aim that brings to life the energies of the sermon is to interact with the members of the Christian community, in order to shape their mentality and to develop new horizons of understanding and behaviour. This change of perspective upon the act of speaking, from I towards you, would later become, through the apostolic missions and the cultural and religious activity of the great spirits of Christianity, the defining characteristic of the communication that ensured the diffusion of the Bible. In other words, unlike the Ancient (pagan) orator, skilled craftsman in exploring the persuasive and stylistic potential of the facts of language, regardless of their truth value, the Medieval (Christian) orator, imbeds in his speech his qualities of authorized interpreter of the biblical text and defender of faith (Clarke, 1996, p. 153). Inspired by the revealed truth of the sacred text, the preacher no longer values the verbal ornaments of his speech but the understanding of and efficient commentary on the teachings of faith, and so, the persuasive and expressive identity of the sermon is shaped by the triad Scripture - preacherbelievers (Kneidel, 2006, p. 362).

According to various researchers, the first medieval treaty on Christian rhetoric is St. Augustine's work, De doctrina christiana, written in two stages, three decades apart (396-426). The volume "foregrounds the problem of Christian eloquence-its legitimacy, functions and principles-and convincingly presents, with examples and arguments, the literary and pedagogical virtues of the sacred text" (Wald, in Augustin, 2002, p. 9). Organized in four books, the work stemmed from the author's experience as a teacher of rhetoric as well as on his prodigious preaching activity. Regarding the rhetoric repertoire, St. Augustine capitalized on the works of Cicero. In fact, for the founders of the Christian rhetoric up to the thirteenth century, when the Western scholars discover and translate Aristotle's works, "Cicero is the unquestioned magister eloquentie" (Murphy, 2001, p. 106-107). This classical model is adapted and accommodated to a task of utmost complexity, the revelation of the Christian doctrine, by highlighting the eloquence patterns from the sacred text and from the founding apologetics. The vast process of converting the classical culture ${ }^{3}$ implied not only the critical evaluation of the principles, rules and current techniques of the classical oratory, but also the constitution of new tenets, consistent with the task of preaching God's word.

In the age of St. Augustine's De doctrina christiana, "there was a need for a new rhetoric, as there was the danger that the sacred eloquence be impregnated by the sophistic atmosphere and excess of erudition" (Wald, in Augustin, 2002, p. 17); consequently, the distinguished and enlightened scholar must have felt the need to counteract this slide towards technicality by drafting a textbook of good practices in the art of preaching, and this scholarly achievement proved very fruitful and influential ${ }^{4}$. Therefore, beginning with the fourth century, a declared preference for clarity, simplicity and accessibility is noticed with the great Christian rhetoricians, despite their solid training in the classical culture. The term homily, from the Church Lat. homilia - in its turn derived from the Gr. homilia, 'communion, conversation'-must be understood as 'sermo familiaris in Evangelium' and emphasizes the qualities of this efficient style of

\footnotetext{
${ }^{3}$ A very good example of conversion is Augustine's text itself where the biblical quote is in the neighbourhood of fragments from the great Ancient authors: Plato, Hesiod, Vergil, Cicero, Varro, etc.

4"De doctrina christiana was included in the curriculum of the monastic schools, and became a model and a guide, both didactically as well as homiletically, as it was equally influential and authoritative, especially during the Western Middle Ages, but also in the centuries to follow." (Wald, in Augustin, 2002, p. 25).
} 
preaching, through which the priests interpret the meanings of the biblical fragments read during the liturgy so that the believers could understand them.

We will focus on three important aspects from the multitude of observations, comments and examples that St. Augustine brings to support his views on Christian rhetoric: a) the personality of the Christian orator and his relationship with the audience, b) the aims of preaching and c) the types of elocution that he can employ so that his speech might be vivid.

\section{The discursive personality of the Christian orator}

The Greek and Roman rhetoricians recommended that the orator should have a thorough education, achieved through learning and exercise, but for St. Augustine, the preacher's eloquence is a testimony of faith developed through observation, imitation and practice rather than through a formal process of accumulation of knowledge. The Christian orator acquires the art of preaching more effectively ${ }^{5}$ if he is close to a master and nourishes his spirit on the masters' writings and words, than if he lets himself seized by a mechanism of assimilation of information, deprived of the living substance of the human ministering to the divine. Just as the infants learn how to speak following and imitating the adults, in a similar manner a person can become a good orator "not through the traditional teaching" of eloquence (Augustine, 1995, p. 279), but by reading, imitating and listening to the speeches of eloquent and gifted preachers. This perspective on the formation of the preacher is, undoubtedly, in accordance with the doctrine of the word revealed by God to man, as it appears in the Gospels $\left(M k, 13,11 ; M t, 10,19-20^{6}\right)$ and specifies that, for the Christian orator, the rules of rhetoric are intuitive and not prescriptive.

Eloquence and wisdom are united in the preacher's personality, with the primacy given to the latter. A wise speaker lacking in eloquence may still be useful to his listeners, while a speaker who "is awash with the kind of eloquence that is not wise is particularly dangerous" (Augustine, 1995, p. 283). In St. Augustine's view, true wisdom stems from God, and the preacher's sermon must symbolise the God-given inspiration. The discursive ideal that guides the Christian rhetorician is the biblical text in which one can find "all the qualities and figures of eloquence" (Augustine, 1995, p. 287). The idea that the naturalness and spontaneity of speech do not submit to predetermined, rigid rules, but govern them is consistent with the innovation to consider that the substance of the discourse is more important that its form. What is said is more relevant than the manner in which it is said. The prevalence of the content foregrounds a typical feature of the sermon which is the concern for the listener. He is the one who must be guided towards understanding the truth of the revealed text ${ }^{7}$ and following it in his daily life. According to the first Christian rhetoricians, the orator is no longer a conqueror of the listeners' minds and hearts, but a teacher cultivating the good, caring for the well-being of the believers and placing himself in the service of the community.

Through his manner of being and speaking, the preacher must be a worthy example to follow and this mentality echoes with the precepts of the Greek and Latin rhetoric according to which the orator's authority and prestige naturally stem from his nobility of character. Only the righteous man can become an orator, concludes Quintilian (1968, IV, p. 355), arguing that "if the powers of eloquence serve only to lend arms to crime, there can be nothing more pernicious than eloquence to public and private welfare alike" (idem). Following the words of the apostle Paul (1Tim, 4, 12), St. Augustine does not allude only to the preacher's moral authority, but to all aspects of his life: "Be an example to believers in speech, in conduct, in love, in faith, and in purity” (Augustine, 1995, p. 279). Therefore, it can be concluded that

\footnotetext{
5“[...] given a sharp and eager mind, eloquence is picked up more readily by those who read and listen to the words of the eloquent than by those who follow the rules of eloquence." (Augustine, 1995, p. 279).

6 "Do not worry about what to say or how to say it; for you will be given words to speak when the time comes. For it is not you who speak, but the spirit of your father who speaks within you." (Augustine, 1995, p. 237; cf. KJv, Mt, 10, 19-20).

7 "What is the use of correct speech if it does not meet with the listener's understanding?", rhetorically wonders Augustine (1995, p. 225).
} 
the Christian rhetoric grew on the belief that the greatest force of conviction comes not from the words but from the examples of human conduct moulded on Christ's model.

\section{The aims of preaching}

With respect to the classical triad of the oratorical purposes (docere, delectare, movere), St. Augustine asserts that no preacher should neglect these three rhetorical targets, but he reinterprets them so that they concur with the doctrinary and discursive requirements of Christianity. The preacher's sermon must be heard with understanding, pleasure, and obedience (Augustine, 1995, p. 235). These three goals reflect the degrees of intensity in persuasion. For those who listen to the sermon, understanding implies acceptance, approval and consent which, in turn, favour convictions in mentality and conduct.

The author of De doctrina christiana dedicates memorable pages to these three expressive and persuasive aims and imposes a number of important changes to be discussed below.

A first initiative is to simplify the architecture of discourse, by restraining the rhetorical canon to invention (what is said) and elocution (how it is said). In the Ancient rhetoric, these were the most important stages, and, in order to validate the thesis of the inspired orator (see also Gafton, 1995, p. 30), St. Augustine considers them as the basic pillars in the elaboration of the sermon ${ }^{9}$. The invention is designated to prepare the adequate transmission of an authorized interpretation of the biblical text whereas the elocution must highlight the revealed truth.

In Christian eloquence, the act of understanding is invested with a double orientation, from the authority of the sacred text to the preacher and then, from the text and the Christian orator to the believers he addresses. On the one hand, the preacher, as authorized interpreter, meditates to the significance of the sacred text and, in this context, it is important to note that, during the Middle Ages, the biblical exegesis created a four-fold canon of meaning (cf. Nate, 2006, p. 24): a) literal or historical (sensus literalis), b) allegorical (sensus allegoricus), c) moral or tropological (sensus moralis/tropologicus) and d) anagogic or mystical/eschatological (sensus anagogicus) ${ }^{10}$. On the other hand, the preacher has the duty to reveal to the believers the meaning of the scriptural verses read during the religious service, so that they adhere, in conduct, to the teachings of faith. The listeners' pleasure and impulse to act is rooted in understanding and, through understanding, in the their willingness to embrace and share the biblical truth.

As a result, the second change is to separate the capital role given to understanding from the derived roles of pleasure and obedience. Understanding is seen as the necessity to instruct the followers in the light of the biblical truth, in determining them to be attentive to what is said, while the pleasure and the obedience are goals to be reached only if the understanding is efficiently ensured.

The repertoire of strategies employed to delight and move the listeners is carefully elaborated and exemplified. Each time the preacher "wishes to delight the person he is speaking to, or to move him, he

\footnotetext{
${ }^{8} \mathrm{~A}$ more appropriate term to describe the behaviour that must be induced to the public is that of submission. For the Christian, the submission is the pledge as well as the practice to unabatedly follow the path towards redemption, to follow Christ.

9 "From the thirteenth century onward, we have vastly more evidence for the range of preaching practices. Sermons can be divided roughly into three types: a straightforward, simple exposition of scripture; the methods of exposition and division associated with the learned style of university sermons; and popular (especially vernacular) preaching by means of anecdote, fable, saint's legend, miracle story and moralized exempla $[\ldots]$

The form of sermons outlined most typically by artes predicandi consists of six parts: 1 . theme: a quotation from scripture (from the day's liturgical readings), followed by a prayer; 2 . protheme, which is the exordium of the theme (this could consist of a quotation from another part of scripture that had corresponding relevance to the first quotation); 3 . antetheme: the introduction of the theme, a restatement that sets forth the purpose of the sermon; 4 . division of the theme, into three or further multiples of three, with authorities cited to "prove" each division; this was both a part of the sermon and the key exegetical and inventional activity upon which the sermon depended; 5. subdivision of the theme; 6. amplification or dilation (or "distinction") of each of the divisions and subdivisions." (Copeland \& Ziolkowski, 2006, p. 494-495).

${ }^{10}$ For example, according to St. John Cassian, the name "Jerusalem" is invested in the sacred text with the following values: historical ("city"), allegorical ("Church of Christ"), moral ("the human soul") and anagogic ("The Jerusalem of the above, heavenly city, mother of us all”, cf. Gal, 4, 26).
} 
will not achieve this by speaking anyhow; it makes a difference what style he uses for this purpose. A hearer must be delighted, so that he can be gripped and made to listen, and moved so that he can be impelled to action. Your hearer is delighted if you speak agreeably, and moved if he values what you promise, fears what you threaten, hates what you condemn, embraces what you commend, and rues the thing which you insist that he must regret; and if he rejoices at what you set forth in your preaching as something joyful, pities those whom by your words you present to his mind's eye as miserable, and shuns those whom with terrifying language you urge him to avoid. There are other things too in this grand style of eloquence which can be done to move the minds of listeners, the purpose being not to make known to them what they must do, but to make them do what they already know must be done." (Augustine, 1995, p. 229, 231).

If it is accepted that, in St. Augustine's view, the informative function of the speech expands into a formative function, one can consider that the instructive role is objective, namely, it refers to what is said, while the roles derived, that is pleasure and obedience, are (inter)subjective, namely, they highlight the personalities of the protagonists of the act of communication (the orator and the listener) and the relationships between them. This distinction is pertinent and extremely useful in underlining that the charm and power of eloquence spring from the capacity of the human language to express what the human being perceives as essential and truthful.

A third important shift promoted in De doctrina christiana is to associate the energies of persuasion which are the logos, the ethos and the pathos, with the triad of aims targeted by the preacher, the understanding, the pleasure and the obedience, and this revision of the classical patterns is visible mainly in the rearrangement within the three-styles system.

\section{Types of elocution}

In Ancient rhetoric, speech composition and delivery are governed by the rules of the adopted rhetorical genre and matched to the circumstances, both real and discursively represented. From case to case, the orator may appeal to distinct types of elocution. The simple style is used informatively, the middle style resides in harmony, elegance and balance, while the grand style is richly adorned.

St. Augustine adapts the traditional model to the new world of Christian discursive realities. In his vision, the preacher adopts the simple style when he instructs, the middle style when he makes comments and the grand style when the audience must be urged to live in accordance with the letter and the spirit of the sacred text, to pass from understanding to conduct, to convert words into action. In Christian oratory, the essence of the simple style lies in the depth of reasoning ${ }^{11}$, its dominant trait being the logos, the middle style is characterized by argumentative balance ${ }^{12}$, its dominant trait being the ethos, and the main feature of the grand style is vitality ${ }^{13}$, its dominant trait being the pathos. In other words, the simple style acts "on the mind or reason, not on feelings or the will, it aims at changing the line of thoughts," the middle style "may, by its virtue of appraisal or blame, influence the audience and make them change their way of life, but not directly or necessarily," and the grand style "touches the soul and may ultimately cause a change in the way of life." (Wald, in Augustin, 2002, p. 441).

By reference to the Ancient precepts, the enlightened scholar lays down two principles that are meant to guide the persuasive and expressive efficiency of the act of preaching. The first one is the principle of

\footnotetext{
11 "So it is part of the teacher's task not just to reveal what is hidden and solve knotty problems but also, while doing this, to anticipate other questions which may arise, in case they undermine or refute what we are saying." (Augustine, 1995, p. 247)

${ }^{12}$ In the ecclesiastical oratory, "we should use the embellishment of the middle style thoughtfully, and not ostentatiously." (Augustine, 1995, p. 273)

13 "What especially differentiates the grand style from the mixed style is that it is not so much embellished with verbal ornament as inflamed by heartfelt emotion. It has room for almost all those ornaments, but if they are not there they are not missed. It is borne along by its own momentum, and derives its beauty of expression, if indeed this emerges, from the power of its subject-matter, and not the pursuit of elegance. It is sufficiently equipped for its purpose if appropriate words follow not from a search for elaborate vocabulary but from the promptings of a passionate heart." (Augustine, 1995, p. 251, 253)
} 
Ioan Milică

stylistic adequacy. To reach maximum efficiency, the preacher is free to use, in the same sermon, all three types of elocution ${ }^{14}$. The diverse and harmonious use of the resources pertaining to the three styles is thoroughly discussed from Aristotle to Quintilian. The latter asserts that the equilibrium of the elocution types ensures the success of the speech: "Thus the works of the orator will be great not extravagant, sublime not bombastic, bold not rash, severe but not gloomy, grave but not slow, rich but not luxuriant, pleasing but not effeminate, grand but not grandiose. It is the same with other qualities: the mean is safest, for the worst of all faults is to fly to extremes." (Quintilian, 1968, IV, p. 495).

St. Augustine refines this theoretical frame showing that the three discursive goals: to understand, to please and to obey are tightly interlocked in the discourse. According to this principle that could be named the principle of the persuasive unity, to understand, to please and to obey support one another: "Who does not realize that a person who is not understood cannot be listened to either with pleasure or with obedience?" rhetorically wonders Augustine (1995, p. 275), before claiming that the aims targeted by the preacher are organized, according to the circumstance, around a dominant one, the other two being submitted to this persuasive centre. Even if the simple style mainly aims at the clarity of reasoning (understanding), the pleasure and the obedience are not excluded as secondary goals. In the middle style, the primacy is given to pleasure, but the understanding and the obedience may likewise become manifest. Finally, moving a heart of stone which is the goal of the grand style is not possible unless the speaker "is also listened to with understanding and pleasure as well." (Augustine, 1995, p. 277).

The theoretical aspects are not the only ones that demonstrate St. Augustine's crucial contribution to the foundation of the Christian rhetoric, equally important are also the text analyses that the author provides in order to demonstrate that the Scripture is a prototype of eloquence. If we take into account the multitude of examples, it is not far-fetched to consider De doctrina christiana a highly valuable guide in biblical hermeneutics and Christian rhetoric. St. Augustine is the first great Christian scholar who "expatiates on the usefulness of rhetoric for the Christian mission of interpretation and promulgation of the word of God" (Habinek, 2005, p. 89). Unlike the pre-Christian thinkers and rhetoricians, whose rhetorical conceptions relied in the communicative craft of convincingly interpreting a specific reality, for the Christian orators, and St. Augustine insists on this, ars bene dicendi is servient to the communication of the truth revealed by the sacred text. In his mind, "discovery or invention is no longer the creation of arguments or the identification of the best means of persuasion in the matter at hand, but the discovery of the truth of scripture. And the rest of rhetoric (in his case, style, memory, and performance) considers the means through which that truth might be conveyed to a given audience. In effect, then, it is the Christian writers, much more than their pagan counterparts, who disseminate the view that style is an elective means of communicating a substance that is always already there." (idem).

\section{Conclusions}

The Christian rhetorical patrimony enriches the Ancient rhetorical legacy, by opening a new perspective whose importance cannot be neglected in the field of rhetorical and stylistic research:

a) through the adoption and adaptation of the Ancient rhetorical tenets, the founders of the Christian hermeneutics and rhetoric develop a normative tradition that gives a fresh impetus to oratorical art and analysis (Murphy, 2001, p. 61);

b) according to the founders of Christian rhetoric, the supreme goal of the art of preaching is not to move the minds and hearts of the audiences, as the ancient scholars recommended, but to guide the human being towards the truth of the sacred text;

14"Nobody should think that it is against the rules of the art to combine these styles. On the contrary, our discourse should be varied by using all three, as far as is possible without impropriety. When a speech carries on in a single style, it is less absorbing for the listener, but when there is transition from one style to another it has a smoother flow, even if it is rather long." (Augustine, 1995, p. 267) 
c) for the Christian apologists, the ideal of eloquence must be found in the letter and spirit of the biblical text;

d) the Christian orator must be a living example, who convinces more through his conduct than through the craft in composing beautifully adorned and well-argumented speeches;

e) the preacher's discursive efficiency is founded on the act of matching the linguistic resources to the expressive and persuasive requirements of the communicative circumstances and of the hierarchically ordered unity of the goals targeted by the orator.

\section{Bibliography}

Augustin 2002 = Sf. Augustin, De doctrina christiana: introducere în exegeza biblică, traducere de Marius Ciucă, introducere, note și bibliografie de Lucia Wald, Editura Humanitas, București, 2002.

Augustine 1995 = St. Augustine, De Doctrina Christiana, edited and translated by R. P. H. Green, Clarendon Press, Oxford, 1995, Crossref.

Clarke, M. L. (1996). Rhetoric at Rome: a Historical Survey, third edition, revised and with a new introduction by D. H. Berry, Routledge, London, New York, Crossref.

Copeland, R. \& Ziolkowski, J. (2006). Medieval rhetoric, in Sloane, Thomas O., (coord.), Encyclopedia of Rhetoric, Oxford University Press, p. 487-497, Crossref.

Dowden, K. (2007). Rhetoric and Religion, în Worthington, Ian (ed.), A Companion to Greek Rhetoric, Blackwell Publishing, p. 320-333.

Gafton, Al. (1995). O ipoteză interpretativă asupra sintagmei paulinice „a vorbi în limbi”, in “Echidistanțe”, nr. 7-8, p. 29-31.

Habinek, Th. (2005). Ancient Rhetoric and Oratory, Blackwell Publishing, Crossref.

Knape, J. (2008). Rhetorik und Stilistik des Mittelalters, in Fix, U., Gardt, A. \& Knape, J. (Hrsg.), Rhetorik und Stilistik. Ein Internationales Handbuch historischer und systematischer Forschung/ Rhetoric and Stylistics. An International Handbook of Historical and Systematic Research, vol. I, Walter de Gruyter, Berlin, New York, p. 55-72.

Kneidel, G. (2006). Homiletics, in Sloane, Thomas O., (coord.), Encyclopedia of Rhetoric, Oxford University Press, p. 362-366, Crossref.

Murphy, J.J. (2001). Rhetoric in the Middle Ages. A History of Rhetorical Theory from Saint Augustine to the Rennaissance, Arizona Center for Medieval and Renaissance Studies.

Nate, R. (2006). Allegory, in Sloane, Thomas O., (coord.), Encyclopedia of Rhetoric, Oxford University Press, p. 23-26, Crossref. Quintilian (1968). Institutio oratoria, with an English translation by H.E. Butler, sixth edition, 4 vols., Harvard University Press, Cambridge Massachusetts, William Heinemann Ltd., London. 